\title{
TECHNICAL AND TECHNOLOGICAL ANALYSIS OF INDIVIDUAL WASTEWATER TREATMENT SYSTEMS
}

\author{
Anita JAKUBASZEK ${ }^{1}$, Artur STADNIK \\ University of Zielona Gora, Zielona Góra, Poland
}

\begin{abstract}
The article characterises most frequently selected by investors individual mechanical and biological sewage treatment systems. On the basis of gathered information and technical documentation, technical and technological analysis of the devices was conducted. Assess factors include technology, structure, workflow, control, exploitation conditions, and sewage treatment system effectiveness. On the basis of conducted analysis, limited possibility of using activated sludge wastewater treatment in a flow system was established due to the difficulty of stabilizing the whole system. An optimal solution for individual wastewater treatment system are solutions of activated sludge technology in SBR system and hybrid technologies.
\end{abstract}

Keywords: individual sewage treatment systems, biological technologies

\section{INTRODUCTION}

Water consumption is connected to wastewater production and collection. In large cities and agglomerations over $15000 \mathrm{PE}$ (Population Equivalent), the issue of wastewater management is resolved [3,9], while in smaller agglomerations and primarily in the country, it still requires particular attention. During the last few years, numerous water and sewage investments were realized, however, still large disproportion in access to the water and sewage systems exists between city and country. It is particularly visible in the country, where almost $60 \%$ of inhabitants

\footnotetext{
${ }^{1}$ Corresponding author: University of Zielona Gora, Institute of Environmental Engineering, Szafrana st 15, 65-246 Zielona Góra, Poland; e-mail: a.jakubaszek@iis.uz.zgora.pl, tel. +48683282396
} 
does not have access to a sewage system. Situation in the city stands decidedly better, with only $10 \%$ of inhabitants not using sewage system $[3,7,13]$.

Habitants of non-canalised areas use onsite sewage collection systems: holding tanks and onsite wastewater treatment systems. 2333 thousands of the devices functioned in Poland in 2016, ca. 91\% of which were holding tanks. For the last few years, a systematic decrease of holding tanks number has been noted, with simultaneous increase of onsite wastewater treatment systems number. Number of holding tanks decreased from about 2136 thousands in 2015 to 2117 thousands in 2016 (by $0.9 \%$ ), while number of onsite wastewater treatment systems increased from about 203 thousands in 2015 to about 217 thousands in 2016 [3]. Amount of wastewater production in the country will be increasing due to easier access to water systems, building of new houses, and higher standard of resident buildings equipment. Thus, investing in individual wastewater treatment systems in areas of scattered housing, where common sewage systems are most frequently absent, becomes necessary $[1,4,5,6]$.

In the last few years, onsite sewage collection systems have been gaining more and more popularity. It is connected primarily to decidedly lower cost of system purchase and relatively low exploitation costs. The basis of onsite wastewater treatment system selection should be not only the economic criterium, but also technological and environmental aspects. The best solutions should be technologically effective, environmentally friendly, and acceptable in economic and exploitative aspects $[4,5,8,10]$.

\section{WASTEWATER TREATMENT SYSTEMS REVIEW}

Activated sludge is a popular and effective method of wastewater treatment, however, the technology has certain requirements which must be met to ensure proper removal of organic compounds, nitrogen, and phosphorus, which is more and more frequently required also in small systems [1,5,11,12].

On the basis of technical documentation, a review of the most frequently selected onsite wastewater treatment systems was prepared. The comparison consist of system of similar wastewater flow - ca. $0.9 \mathrm{~m}^{3} / \mathrm{d}$, intended for $6 \mathrm{PE}$ [2]. Analysed solutions were divided into three categories due to wastewater treatment technology: with low-rate activated sludge, bacterial bed, and hybrid technologies (Fig. 1). 


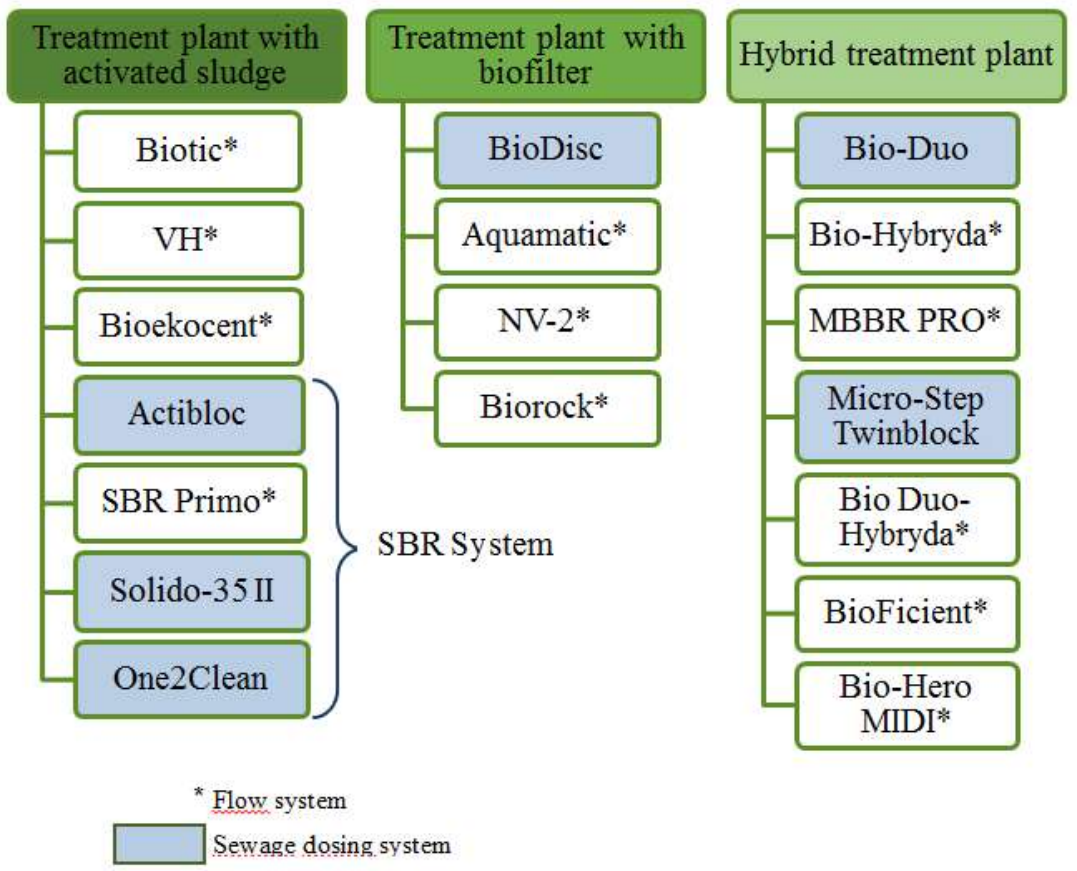

Fig.1. Technologies of individual sewage treatment systems

Solutions utilising activated sludge technology in a classic flow system are: Biotic, VH, and BioEkocent (Fig. 1). A wastewater treatment system with a classic flow system is not the best solution due to exploitation issues, thus, they are not recommended for wastewater treatment systems of low flow (0.5-1.0 $\mathrm{m}^{3} / \mathrm{d}$ ) [Błażejewski, 2003]. In Actibloc, SBR Primo, Solido-35 II, and One2Clean wastewater treatment systems, treatment process is realised in a sequential batch reactors (SBR). The systems use pumps, transferring pre-treated wastewater into the bioreactor (Fig. 1). SBR solutions and other batch systems equipped with correctly designed sedimentation tanks belong to systems of decidedly higher functioning stability, despite significantly uneven raw sewage influx.

Wastewater treatment systems utilising activated sludge technology most frequently consist of one tank, divided into chambers with barriers. BioEkocent system is built of three vertical tanks, while Actibloc system has a form of two chambers. The largest active volume allowing to level varying amounts of wastewater influx have wastewater treatment systems Actibloc $-5.0 \mathrm{~m}^{3}$ and One2Clean $-4.8 \mathrm{~m}^{3}$ (Tab. 2) [2]. 
Table 1. Sewage treatment systems with activated sludge [2]

\begin{tabular}{|c|c|l|c|}
\hline $\begin{array}{c}\text { Wastewater } \\
\text { treatment } \\
\text { plant }\end{array}$ & $\begin{array}{c}\text { Flow } \\
{\left[\mathrm{m}^{3} / \mathrm{d}\right]}\end{array}$ & \multicolumn{1}{|c|}{ Structure } & $\begin{array}{c}\text { System } \\
\text { active } \\
\text { volume } \\
{\left[\mathrm{m}^{3}\right]}\end{array}$ \\
\hline Biotic & 0.90 & $\begin{array}{l}\text { Monolithic tank divided into three areas: } \\
\text { 1-initial, with waste dissolving aerial system } \\
\text { (without standard primary sedimentation tank), 2- } \\
\text { bioreactor, 3- secondary sedimentation tank }\end{array}$ & 2.5 \\
\hline VH & 0.81 & $\begin{array}{l}\text { Monolithic tank divided into six areas of various } \\
\text { oxygen concentration. First area - denitrification, } \\
\text { lack of standard primary sedimentation tank }\end{array}$ & 2.8 \\
\hline BioEkocent & 0.75 & $\begin{array}{l}\text { Three tanks of 1.1m }{ }^{3} \text { volume } \\
\text { 1-primary sedimentation tank, 2-bioreactor, } \\
\text { 3--secondary sedimentation tank }\end{array}$ & 3.3 \\
\hline SBR Primo & 0.90 & $\begin{array}{l}\text { Singular tank divided into two areas: 1-primary } \\
\text { sedimentation tank, 2-bioreactor }\end{array}$ & 3.4 \\
\hline Actibloc & 0.90 & $\begin{array}{l}\text { Two tanks of 2.5m }{ }^{3} \text { volume } \\
\text { 1-primary sedimentation tank, 2-bioreactor }\end{array}$ & 5.0 \\
\hline Solido-35 II & 0.90 & $\begin{array}{l}\text { Singular tank divided into two areas: 1-primary } \\
\text { sedimentation tank, 2-bioreactor }\end{array}$ & 3.5 \\
\hline One2Clean & 1.05 & $\begin{array}{l}\text { Monolithic tank, mechanical and biological } \\
\text { treatment conducted in the same chamber }\end{array}$ & 4.8 \\
\hline
\end{tabular}

Bacterial beds characterise with lower sensitivity to changing quantitative and qualitive load of supplied wastewater. Disadvantage of bacterial bed technology is hindered simultaneous removal of organic compunds, nitogen, and phosphorus. BioDisc and STM Aquamatic wastewater treatment systems use rotating disc system, Biorock utilises trickling filter, while NV-2 is equipped with immersed membrane bioreactor. BioDisc and NV-2 systems are made in form of monolithic tanks, while Aquamatic and Biorock are based on two tanks. BioDisc wastewater treatment system has he largest active volume in the group of $4.8 \mathrm{~m}^{3}$ (Tab. 2).

Hybrid wastewater treatment systems utilise advantages of suspended activated sludge and biofilm. Hybrid reactor filling is most frequently made of plastics, fibrous materials or polyurethane foam. Hybrid systems may have one shared chamber for activated sludge and bacterial bed, or two chambers, one of which fulfils role of the bacterial bed, and the other is an activated sludge chamber. Hybrid wastewater treatment systems may work in a flow or a batch system. Among the described systems, only Bio-Duo system is equipped in pump dosing pre-treated wastewater into the bioreactor, while the other systems utilise flow method. 
Table 2. Sewage treatment systems with biofilter [2]

\begin{tabular}{|c|c|c|c|c|}
\hline $\begin{array}{l}\text { Wastewater } \\
\text { treatment } \\
\text { plant }\end{array}$ & $\left.\mid \begin{array}{l}\text { Flow } \\
{\left[\mathrm{m}^{3} / \mathrm{d}\right]}\end{array}\right]$ & $\begin{array}{l}\text { Technolog } \\
\text { y }\end{array}$ & Konstrukcja & $\begin{array}{l}\text { System } \\
\text { active } \\
\text { volume } \\
{\left[\mathrm{m}^{3}\right]}\end{array}$ \\
\hline BioDisc & 1.20 & $\begin{array}{l}\text { rotating } \\
\text { disc system }\end{array}$ & $\begin{array}{l}\text { Monolithic tank divided into four areas: } \\
\text { 1-primary sedimentation tank }\left(3.0 \mathrm{~m}^{3}\right) \\
2 \quad \text { and } 3 \text {-bacterial bed }\left(1.4 \mathrm{~m}^{3}\right) \\
\text { 3- secondary sedimentation tank }\left(0.42 \mathrm{~m}^{3}\right)\end{array}$ & 4.8 \\
\hline Aquamatic & 0.75 & $\begin{array}{l}\text { rotating } \\
\text { disc system }\end{array}$ & $\begin{array}{l}\text { Two tanks: } \\
\text { 1-two-chamber primary sedimentation } \\
\text { tank }\left(2.0 \mathrm{~m}^{3}\right), 2 \text { - two chambers: bioreactor } \\
\left(1.3 \mathrm{~m}^{3}\right) \text { and secondary sedimentation tank } \\
\left(0.51 \mathrm{~m}^{3}\right)\end{array}$ & 3.8 \\
\hline NV-2 & 0.90 & $\begin{array}{l}\text { immersed } \\
\text { membrane } \\
\text { bioreactor }\end{array}$ & $\begin{array}{l}\text { Monolithic tank divided into two } \\
\text { chambers: bioreactor and secondary } \\
\text { sedimentation tank. Basic version of the } \\
\text { system does not have a primary } \\
\text { sedimentation tank }\end{array}$ & - \\
\hline Biorock & 0.90 & $\begin{array}{l}\text { trickling } \\
\text { filter }\end{array}$ & $\begin{array}{l}\text { Two tanks: } \\
\text { 1- primary sedimentation tank }-2.5 \mathrm{~m}^{3} \text {, } \\
\text { 2-bioreactor with filling - } 1.5 \mathrm{~m}^{3} \text {. No } \\
\text { secondary sedimentation tank or sludge } \\
\text { recirculation }\end{array}$ & 4.0 \\
\hline
\end{tabular}

The largest active volume have systems Micro-Step Twinblock $-5.2 \mathrm{~m}^{3}$ and BioDuo $-5.0 \mathrm{~m}^{3}$ (Tab. 3). These solutions are more resistant to hydraulic overload and can take larger wastewater amount than classic activated sludge system due to the option of gathering larger biomass amount.

Table 3. Hybrid sewage treatment systems [2]

\begin{tabular}{|c|c|c|c|}
\hline $\begin{array}{c}\text { Wastewater } \\
\text { treatment } \\
\text { plant }\end{array}$ & $\begin{array}{c}\text { Flow } \\
{\left[\mathrm{m}^{3} / \mathrm{d}\right]}\end{array}$ & \multicolumn{1}{|c|}{ Structure } & $\begin{array}{c}\text { System } \\
\text { active } \\
\text { volume } \\
{\left[\mathrm{m}^{3}\right]}\end{array}$ \\
\hline Bio-Duo & 0.90 & $\begin{array}{l}\text { Two tanks: } \\
1-\text { primary sedimentation tank }\left(2.5 \mathrm{~m}^{3}\right), \\
\text { 2- bioreactor }\left(2.5 \mathrm{~m}^{3}\right) \text { divided into two areas: } \\
\text { bacterial bed and activated sludge }\end{array}$ & 5.0 \\
\hline
\end{tabular}




\begin{tabular}{|c|c|l|c|}
\hline Bio-Hybryda & 0.75 & $\begin{array}{l}\text { Monolithic tank divided into three chambers: } \\
\text { primary sedimentation tank }\left(1.2 \mathrm{~m}^{3}\right), \text { bacterial bed } \\
\left(0.8 \mathrm{~m}^{3}\right), \text { secondary sedimentation tank }\left(0.5 \mathrm{~m}^{3}\right)\end{array}$ & 2.5 \\
\hline MBBR Pro & 0.90 & $\begin{array}{l}\text { Monolithic tank divided into three chambers: } \\
\text { primary sedimentation tank }\left(1.26 \mathrm{~m}^{3}\right), \text { fluidised } \\
\text { bacterial bed }\left(0.66 \mathrm{~m}^{3}\right), \text { secondary sedimentation } \\
\text { tank }\left(0.64 \mathrm{~m}^{3}\right)\end{array}$ & 2.6 \\
\hline $\begin{array}{c}\text { Micro-Step } \\
\text { Twinblock }\end{array}$ & 0,90 & $\begin{array}{l}\text { Monolithic tank divided into three chambers: } \\
\text { primary sedimentation tank }\left(2.6 \mathrm{~m}^{3}\right), \text { bacterial bed } \\
\left(1.6 \mathrm{~m}^{3}\right), \text { secondary sedimentation tank }\left(1.00 \mathrm{~m}^{3}\right)\end{array}$ & 5.2 \\
\hline $\begin{array}{c}\text { Bio Duo- } \\
\text { Hybryda }\end{array}$ & 0,90 & $\begin{array}{l}\text { Monolithic tank divided into four areas: primary } \\
\text { sedimentation tank with oil separator, two biological } \\
\text { reactors }(\text { low-rate activated sludge and fluidised } \\
\text { bacterial bed), secondary sedimentation tank }\end{array}$ & 3.0 \\
\hline BioFicient & 0.90 & $\begin{array}{l}\text { Singular tank divided into four areas: primary } \\
\text { sedimentation tank, two biological reactors (low- } \\
\text { rate activated sludge and fluidised bacterial bed }),\end{array}$ & 3.0 \\
\hline secondary sedimentation tank
\end{tabular}

\subsection{Equipment of individual wastewater treatment systems}

Structure of wastewater treatment system, its equipment and workflow are the most important factors influencing waste removal effectiveness. Utilising proper equipment improves wastewater treatment system functioning but also increases investment cost.

Wastewater collected in a single household characterises with high variability of quantity and composition throughout a day. Primary sedimentation tank may fulfil additional function of a holding tank and level wastewater influx variables, which will optimise bioreactor work. Onsite wastewater treatment systems are equipped with sedimentation tanks of various volume and shape. The structure influences mechanical treatment of raw sewage quality and sludge disposal frequency. 


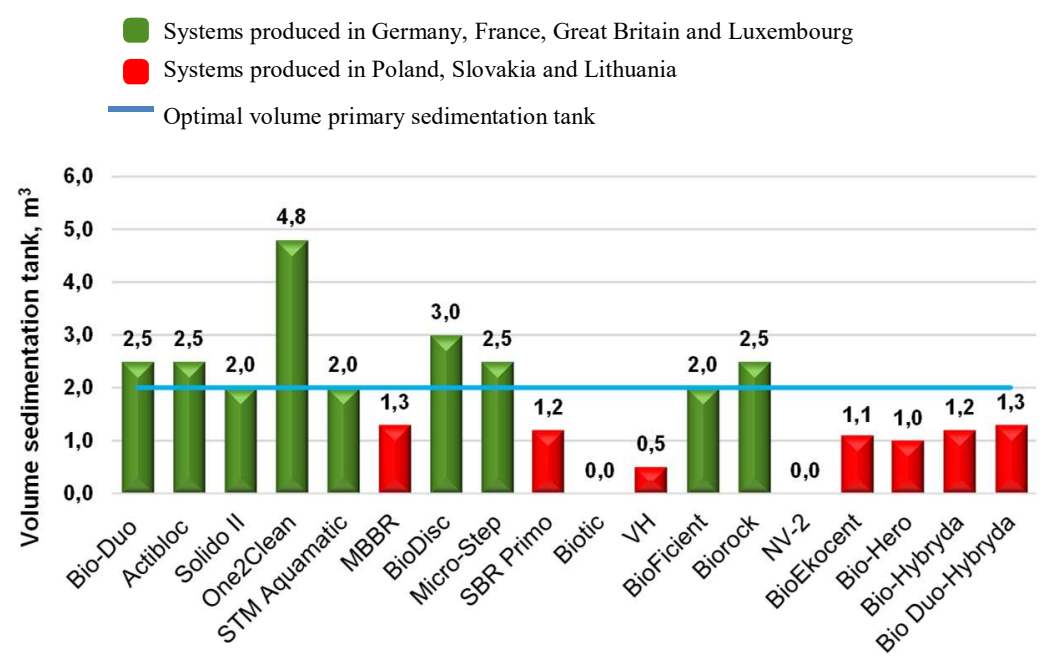

Fig. 2. Primary sedimentation tank volume in the analysed wastewater treatment systems

Fig. 2 presents volumes of primary sedimentation tanks of examined solutions. SBR Primo, VH, BioEkocent, Bio-Hybryda, Bio-Hero, and MBBR devices have sedimentation tanks of volume of $0.5 \mathrm{~m}^{3}-1.3 \mathrm{~m}^{3}$, Biotic is a singular tank with a separated chamber with waste dissolving aerial system. NV-2 system is not equipped with primary sedimentation tank, wastewater is transferred directly into the bacterial bed. There is a risk of solid fractions or oils in the wastewater accumulating in the bed filling and thus wastewater treatment system ceasing to function. While PN EN 12566-3 norm does not establish proper volume of a sedimentation tank, the optimal volume equals from $2 \mathrm{~m}^{3}$ to $3 \mathrm{~m}^{3}$. According to the DIN 4261 norm, it is recommended to assume unitary volume of sedimentation tank equal $0.3 \mathrm{~m}^{3} / \mathrm{M}$, while total volume should not be lower than $3 \mathrm{~m}^{3}$. Meanwhile, according to the PN-EN 12566-1:2016-10 norm, minimal volume of sedimentation tank should equal $2 \mathrm{~m}^{3}$ [12].

Primary sedimentation tanks usually have very similar equipment. Due to utilising influx deflector connected to properly prolonged structure of a sedimentation tank, wastewater stream is evenly distributed. Some sedimentation tanks (of the Actibloc, Solido-35, Micro-Step, BioDisc, and BioDuo systems) are also equipped in pumps, which release pre-treated wastewater into bioreactor in batches. BioDisc system utilises a ladle system for that purpose. Analysed wastewater treatment systems differ from one another also in bioreactor equipment. Wastewater treatment systems working in a flow system, usually have an aeration chamber separate from the secondary sedimentation tank. Only in SBR systems the bioreactor is simultaneously an aeration chamber and a 
secondary sedimentation tank. There is an exception in form of One2Clean system, the tank of which simultaneously fulfil roles of a primary sedimentation tank, a bioreactor, and a secondary sedimentation tank. It is equipped only with a ventilation diffusor and a mammoth pump for treated wastewater transfer into the recipient.

Standard bioreactor is equipped with an aeration system in the form of disc or pipe diffusor, installed at the chamber bottom. In systems such as Micro-Step, Actibloc, Bio-Duo, and BioFicient, the diffusor is attached to a special, easily disassembled element. The handle is made of acid-resistant or plastic tube. The simplest diffusor installation is in Bio-Hybryda 2500 system, where the diffusor is welded to the chamber bottom. Meanwhile in Bioekocent 3300 system, diffusor disc is attached to a standard concrete block, keeping the element on the chamber bottom.

Bioreactors may be equipped with mammoth pumps, used for sludge recirculation and treated wastewater collection. The most elaborate are SBR systems such as Actibloc, Solido, and SBR Primo. Majority of reactors does is not equipped with electric elements, which increases user safety, with an exception of BioDisc system, shaft and bacterial bed discs of which are powered by electric drive, and SBR Primo system, which utilises rotodynamic pumps for treated wastewater collection and recirculation. Electric subassemblies in both solutions should be considered the most sensitive system elements.

Due to the necessity of periodically performing exploitation activities, the devices should be equipped in exploitation-service hatches offering access to elements inside the tank. In order to lower tank cost, producers provide one or two hatches, usually of a small diameter, e.g. Bio-Hybryda system (hatch diameter DN350). A beneficial solution consists of each chamber with its own hatch of proper size. Easy access to the exploitation elements offers Actibloc system -3 hatches, and Bio-Duo system - 4 hatches of large diameter (DN600 and DN700). In systems such as MBBR Pro 6, BioFicient or VH, singular hatches over all chambers are provided, however, their diameters do not offer easy access to exploitation elements. BioDisc system also has only one hatch, but of a large diameter DN2000, and its cover is divided into two parts, which facilitates exploitation and servicing.

\subsection{Wastewater treatment system work automatization}

Automatization of small wastewater treatment systems includes primarily control of aeration blower and driver elements, such as electrovalves or pumps for coagulants dosing. It increases system cost, but optimises its work and is convenient for the user doing exploitation. 
Half of the analysed wastewater treatment systems use dedicated control. Control automation of their wastewater treatment systems offer mainly German and French producers (Tab. 4).

Table 4. Control automation in wastewater treatment plants [2]

\begin{tabular}{|l|l|l|l|l|}
\hline \multicolumn{2}{|l|}{$\begin{array}{l}\text { Wastewater treatment plant } \\
\text { with dedicated automatics }\end{array}$} & \multicolumn{3}{|c|}{ Wastewater treatment plant without dedicated } \\
\hline Bio-Duo & France & Biotic & Poland & Mechanical clock \\
\hline Actibloc & France & VH & Slovakia & Mechanical clock \\
\hline Solido II & Germany & BioFicient & Great Britain & Mechanical clock \\
\hline One2Clean & Germany & Biorock & Luxembourg & Lack of automatics \\
\hline Aquamatic & Germany & NV & Lithuania & Lack of automatics \\
\hline MBBR Pro & Poland & BioEkocent & Poland & Mechanical clock \\
\hline BioDisc & Great Britain & Bio-Hero & Poland & Lack of automatics \\
\hline Micro-Step & Germany & Bio-Hybryda & Poland & Digital clock \\
\hline SBR Primo & Poland & Bio-Duo-Hybryda & Poland & Lack of automatics \\
\hline
\end{tabular}

Some wastewater treatment systems use very simple system in the form of mechanical clock, which turns on only the blower according to simple schedules such as 45/15 or 30/30 min. There are also solutions without control, in which the aeration blower works $24 \mathrm{~h} / \mathrm{d}$. Producers which do not provide dedicated automatics along with the standard solution offer the simplest, minimalised solutions devoid of proper driver and control equipment.

Solutions based on dedicated automatics usually use several work algorithms:

- starting algorithm,

- normal work algorithm,

- holiday algorithm - set manually or automatically in time of lessened wastewater influx or lack of it. It consist of shortening the aeration stage - the blower is turned on more frequently, but for decidedly shorter time duration, - overload algorithm - realised in the case of exceeding daily wastewater influx. Controller also supervises functioning of electric and hydraulic elements. In the case of failure, a sound and visual alarm is set off, and information on it is stored in controller memory. Automatics sums up worktime of specific elements, e.g. blower and electrovalves, informing the user of required exploitation service, subassemblies exchange, or annual check-up. 


\subsection{Exploitation, servicing costs, device price}

Many producers do not require the user to do mandatory annual check-up, which checks proper functioning of the systems. Some companies promote theory of "no-service" wastewater treatment system, which takes its toll on the user quickly after system start. Is the system users do not exploit it correctly and do not do annual check-ups, it may result in incorrect system work and low wastewater treatment effectiveness. Basic recommendation for wastewater treatment system exploitation is to control: membrane blower work, activated sludge work, treated wastewater quality, and mechanical elements such as mammoth pumps, aeration diffusor, and automatics. Producers of Actibloc, BioDisc, and Solido-II systems require obligatory servicing in order to reciieve device warranty. The warranty applies mainly to system body and installed driver elements, wastewater treatment effectiveness is not guaranteed. Price of an annual check-up varies from 200 to 350 PLN.

Exploitation cost is influenced also by used electricity, necessary for functioning of membrane blower and other electric elements. Electricity consumption in the analysed solutions varies from $0.36 \mathrm{kWh} / \mathrm{d}$ for MBBR Pro 6 and Micro-Step systems to $1.92 \mathrm{kWh} / \mathrm{d}$ for NV-2 system (Fig. 3). Biorock system which does not require electricity works in a gravitational flow system with bioreactor with a trickling filter.

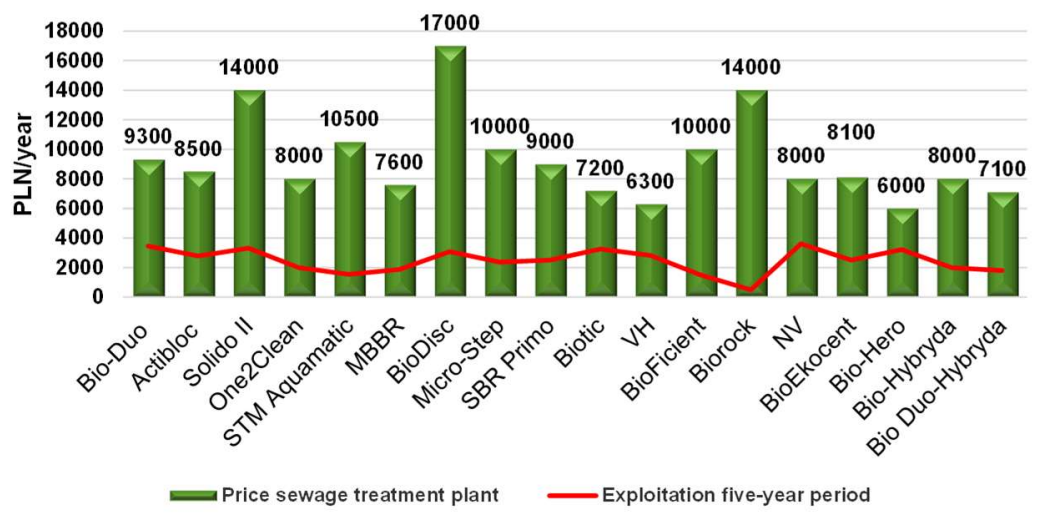

Fig. 3 Analysed wastewater treatment systems energy intensity

Sediments removal frequency also has a considerable influence on wastewater treatment system exploitation cost, since singular removal costs about $150 \div 200$ PLN, regardless of the removed amount. The frequency for devices which have a primary sedimentation tank of small volume is larger (even up to 4 times/year) than for devices equipped in a primary sedimentation tank of optimal volume.

Purchase cost of the discussed wastewater treatment systems varies as well. More advanced technologically devices, equipped in e.g. a large primary sedimentation 
tank or professional automatics are more expensive than the simplest solutions (Fig. 4). Price range is large, e.g. device for 5-6 PE costs from 6000 to 17000 PLN gross. In most cases, the more expensive devices work more effectively, are easier in use, and have lower exploitation costs than the simplest solutions.

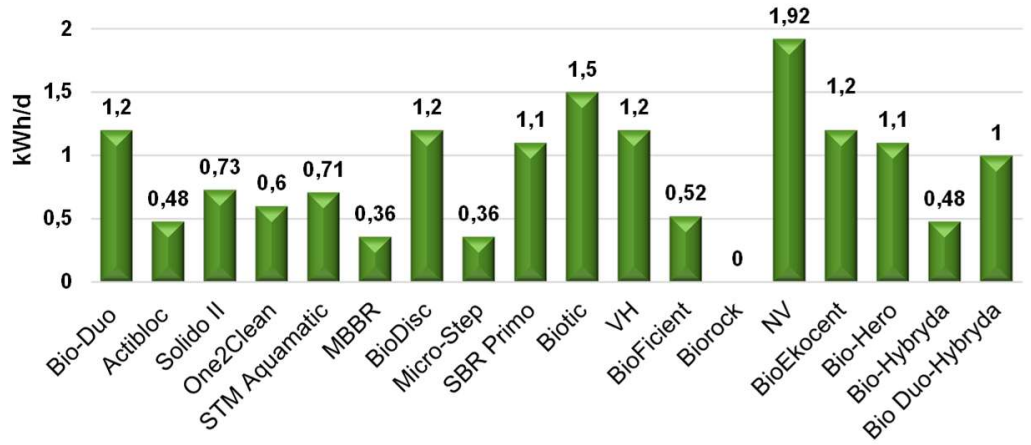

Fig. 4 Costs of purchase and exploitation over 5-year period

When deciding on installing an individual wastewater treatment system, the investor accepts responsibility of its proper exploitation and servicing. DVA Korrespondenz Abwaser Agency emphasises in its report that onsite wastewater treatment systems require particular care, since they work in much harder conditions than communal wastewater treatment systems (high variability of amount and composition of collected wastewater).

Correct functioning of individual systems largely depends on proper system exploitation and servicing.

\section{CONCLUSIONS}

1. The optimal solution for individual household wastewater management are hybrid wastewater treatment systems and SBR systems. They are less sensitive to disadvantageous work conditions and more resistant to hydraulic overload and varying amount of wastewater influx.

2. Stable functioning of the wastewater treatment system is ensured by solutions with appropriately large primary sedimentation tank of optimal volume of about $2 \mathrm{~m}^{3}$, preferably with a system of dosing wastewater from the sedimentation tank into the bioreactor.

3. Technologically advanced solutions will have higher price than the simplest wastewater treatment systems lacking proper equipment. Purchase of cheaper systems results to higher exploitation costs caused by more frequent failures of elements made of worse quality subassemblies. 


\section{REFERENCES}

1. Błażejewski R., Opinia o przydomowych oczyszczalniach ścieków z osadem czynnym. Akademia Rolnicza, Poznań (2003).

2. Dokumentacja techniczno-ruchowa oczyszczalni biologicznych typu: Actibloc 0,9; Bio-Duo 0,9, MBBR PRO6, Solido-35 II, NV-2, Biotic, BioDisc, BioFicient, STM Aquamatic, Biorock, SBR Primo, VH, Bioekocent, One2Clean, Bio-Hybryda, Micro-Step, Bio Duo-Hybryda, Bio-Hero.

3. GUS 2017: Infrastruktura komunalna w 2016r.

4. Heidrich Z., Kalenik M., Podedworna J., Stańko G., Sanitacja wsi, Wydawnictwo Seidel-Przywecki, Warszawa (2008), ss. 373.

5. Heindrich Z. i in., Leksykon Przydomowych oczyszczalni ścieków, Wydawnictwo Seidel-Przywecki, Warszawa (2013), ss. 184.

6. Jakubaszek A., Sadecka Z., The effectiveness of organic pollutants removal in constructed wetland with horizontal sub-surface flow. Civil and Environmental Engineering Reports, No.16. (2015), 69-82.

7. Jakubaszek A., Stadnik A., Ocena pracy przydomowych oczyszczalni ścieków BIO-DUO w pierwszych miesiacach eksploatacji, Zeszyty Naukowe Uniwersytetu Zielonogórskiego. Inżynieria Środowiska, nr 160 (40), s. 45-$55,2015$.

8. Jakubaszek A., Wojciech M., Statistical analysis of nitrogen in the soil of constructed wetland with horizontal sub-surface flow. Civil and Environmental Engineering Reports, No. 12, (2014), 33-43.

9. Ministerstwo Środowiska, Aktualizacja Krajowego Programu Oczyszczania Ścieków Komunalnych, Warszawa (2017).

10. Myszograj S., Bydalek F., Temperature impact of nitrogen transformation in technological system: vertical flow constructed wetland and polishing pond. Civil And Environmental Engineering Reports, No.23, iss. 4, (2016), 125136.

11. Myszograj S., Study on susceptibility of domestic sewage to biodegradation under laboratory conditions. Przemysł Chemiczny, Vol.87, No.5. (2008), 527-530.

12. PN EN 12566-1:2016-10, Małe oczyszczalnie ścieków dla obliczeniowej liczby mieszkańców (OLM) 50. Część 1: Prefabrykowane osadniki gnilne.

13. Sadecka Z., Jedrczak A., Pluciennik-Koropczuk E., Myszograj S., Suchowska-Kisielewicz M., COD fractions in sewage flowing into Polish sewage treatment plants. Chemical and Biochemical Engineering Quarterly, javascript:; Vol.27, No.2. (2013), 185-195. 


\section{TECHNICZNA I TECHNOLOGICZNA ANALIZA INDYWIDUALNYCH MECHANICZNO-BIOLOGICZNYCH OCZYSZCZALNI ŚCIEKÓW}

\section{Streszczenie}

W artykule scharakteryzowano najczęściej wybierane przez inwestorów indywidualne mechaniczno-biologiczne oczyszczalnie ścieków. Na podstawie zebranych informacji oraz dokumentacji techniczno-ruchowej przeprowadzono analizę technicznotechnologiczną urządzeń. Oceniano przyjętą technologię, budowę, system pracy, zastosowane sterowanie oraz warunki eksploatacji i efektywną pracę oczyszczalni.

$\mathrm{Na}$ podstawie przeprowadzonej analizy ustalono ograniczone możliwości stosowania oczyszczalni działających w technologii osadu czynnego w układzie przepływowym z uwagi na trudność w utrzymaniu stabilnej pracy całego systemu. Optymalnym rozwiązaniem oczyszczania ścieków pochodzących z indywidualnych gospodarstw są rozwiązania pracujące $\mathrm{w}$ technologii osadu czynnego w systemie SBR oraz technologie hybrydowe.

Słowa kluczowe: indywidualne systemy oczyszczania ścieków, technologie biologiczne

Editor received the manuscript: 20.11.2017 